\title{
Propaganda política e totalitarismo
}

\section{Political propaganda and totalitarianism}

\author{
Adolpho Queiroz ${ }^{1}$ \\ (adolpho.queiroz@metodista.br) \\ Kleber Carrilho ${ }^{2}$ \\ (kleber.carrilho@metodista.br) \\ http://dx.doi.org/10.5216/cei.v15i2.24572
}

\begin{abstract}
Resumo
Este artigo pretende fazer uma revisão de literatura sobre os principais paradigmas da propaganda política contemporânea. Ele aborda aspectos contemporâneos disseminados a partir das visões teóricas de Jean Maria Domenach, Sergei Tchackotine, Nelson Jahr Garcia, Antonio Gramsci, Max Weber, Pizarroso Quintero, Peter Burke, Maquiavel, entre outros.
\end{abstract}

Palavras-chave: Propaganda. Política. Paradigmas.

\begin{abstract}
This article aims to review the literature on the main paradigms of contemporary political advertising. It addresses contemporary issues spread from the theoretical views of Jean Marie Domenach, Sergei Tchackotine, Jahr Nelson Garcia, Antonio Gramsci, Max Weber, Pizarroso Quintero, Peter Burke, Machiavelli, among others.
\end{abstract}

Keywords: Advertising. Politics. Paradigms.

\section{Poder e comunicação na Antigüidade}

Embora a propaganda política da maneira como conhecemos hoje, tecnicamente desenvolvida com o intuito de conquistar a opinião pública ou um certo número de votos, só tenha aparecido durante o século XX, as relações entre poder e comunicação remontam os mais distantes grupos humanos organizados.

O termo comunicação, pelo fato de poder ser entendido como um derivado do latim communicare, ou seja, "tornar comum, partilhar, repartir, associar, trocar opiniões, conferenciar" (RABAÇA; BARBOSA, 1987, p.151), indica que comunicar inclui a participação, a interação, na emissão e no recebimento de informações.

\footnotetext{
${ }^{1}$ Adolpho Queiroz é pós-doutor em comunicação pela Universidade Federal Fluminense e professor da Universidade Presbiteriana Mackenzie. Brasil, São Paulo.

${ }^{2}$ Kleber Carrilho é doutor em comunicação e professor da Universidade Metodista de São Paulo. Brasil, São Paulo.
} 
Já durante a Antigüidade, nas aldeias, entre os clãs e as tribos, era necessário, para quem mantinha o poder nas mãos, interagir com seus governados, mostrar suas ações, legitimar a origem de seu poder, conquistá-los para as mais diversas atividades em conjunto, fossem elas guerras ou mudanças de territórios.

A conquista e a manutenção do poder sempre foram os principais objetivos de qualquer grupo ou líder político. E isso jamais pôde ser feito de outra maneira senão através de um bom trabalho de comunicação, mesmo quando acompanhado pela força física coercitiva.

Como o poder de todos os agrupamentos humanos na Antigüidade se baseava também na ligação com o místico e com o divino, a comunicação do poder e a comunicação religiosa andaram de mãos dadas por grande parte do tempo. O líder político era também um líder religioso, que em geral tinha o monopólio, ao lado de um pequeno grupo, da comunicação direta com as divindades.

Nas teocracias do Egito, da Mesopotâmia, e mesmo entre os hebreus, herdeiros dos mesopotâmicos, a comunicação então era de primordial importância para a dominação da população. Apenas pequenos grupos, em geral os escribas e os sacerdotes, tinham acesso à comunicação escrita, e tinham a missão de passar ao restante do povo as determinações dos deuses e dos detentores do poder.

Mesmo em civilizações mais distantes da formação do pensamento ocidental, como a chinesa, essa característica se repetia, demonstrando uma relação estreita entre o domínio políticoreligioso e a posse dos instrumentos e dos meios de comunicação.

Segundo alguns autores, essa importância é tão grande que o surgimento da concepção de formação política (um Estado ainda rudimentar) estaria estreitamente ligada ao aparecimento da escrita. De acordo com Cádima

\footnotetext{
Ora, sabendo-se que é com o fim do nomadismo recolector que surgem exatamente as economias produtora e de mercado, e, por acréscimo, se solidificam as sociedades em que se começa a notar a estratificação social, então concluir-se-ia que a escrita estaria também na base da própria emergência das sociedades com Estado. Por aqui se pode ir também ao encontro do que Jack Goody defende, a saber, que exatamente a variação dos modos de comunicar é tão determinante nas mudanças histórico-sociais como a dos modos de produzir. (CÁDIMA, 1996, p. 39).
}

Ainda sobre essa importância da comunicação escrita no desenvolvimento do poder das civilizações da Antigüidade, o antropólogo Lévi-Strauss disse que 
o único fenômeno que nos surge sempre e em todo o lado ligado à aparição da escrita, não só no Mediterrâneo oriental como também na China proto-histórica, e ainda nas regiões da América em que os esboços da escrita apareceram antes da conquista, é o da constituição de sociedades hierarquizadas, compostas de senhores e de escravos, sociedades essas que utilizavam uma certa parte da sua população em trabalho a favor da outra parte. E quando nos pomos a questão sobre quais teriam sido as primeiras utilizações da escrita, é óbvio que essas utilizações foram, em primeiro lugar, as que interessavam ao poder: inventários, catálogos, recenseamentos, leis e ordens (apud CÁDIMA, 1996, p. 40).

Pode-se afirmar então que a comunicação, a escrita e a aquisição da linguagem estão entre os principais elementos fundadores das instituições políticas e sociais, e por isso são determinantes das decisões dos detentores do poder, definindo assim o comportamento dos governados.

A possibilidade de Estados maiores, com controle sobre diversas cidades, também só foi possível com uma máquina de comunicação mais desenvolvida. A possibilidade de transmitir os códigos e os desejos do poder central ficava facilitada com publicações que tinham como finalidade a manutenção do poder.

$\mathrm{Na}$ Grécia, isso pode ser verificado tanto no domínio sobre outros povos quanto na própria organização política das pólis, ou cidades-Estado. A democracia em Atenas, por exemplo, acontecia através de uma desenvolvida estrutura de comunicação, baseada principalmente em grandes discursos, que deixaram conhecidos através dos tempos vários oradores, que eram também chamados de demagogos, aqueles que conquistavam o povo pela palavra.

No momento das decisões na ágora, os defensores de diferentes idéias conquistavam os demais cidadãos pela exposição de seus argumentos, para que as escolhas se dessem da maneira mais racional possível. Era de tal importância a utilização da comunicação persuasiva que os gregos deram origem à retórica, ou o estudo das estruturas do discurso.

A importância dos gregos nessa área é tão grande que, de acordo com Citelli,

falar em persuasão implica, de alguma maneira, retomar certa tradição do discurso clássico - sobretudo conforme exercitado na Grécia - em que podem ser lidas formulações posteriormente desenvolvidas pelos estudos de linguagem. A referência ao espaço cultural e lingüístico do mundo clássico é necessária, visto que a preocupação como domínio da expressão verbal em sua vertente oratória possuía enorme importância entre os gregos. E não poderia ser diferente, pois, praticando um certo conceito de democracia, e tendo de expor publicamente suas idéias, ao tribuno grego cabia manejar com habilidade as estratégias argumentativas com a finalidade de lograr a persuasão dos auditórios. Daí a larga tradição dos sofistas, dos reitores, dos tribunos, aqueles que iam às praças públicas, aos foros, intentando inflamar multidões, alterar pontos de vista, mudar conceitos 
pré-formados. Demóstenes, Quintiliano e Górgias foram alguns desses nomes que ficaram conhecidos pela habilidade com que encaminhavam seus discursos de convencimento. (CITELLI, 2004, p. 7).

Entre os romanos, herdeiros de grande parte das tradições dos gregos, a importância da comunicação na política também foi muito grande. Para a manutenção do poder pelo enorme território conquistado, foi desenvolvida uma espécie de boletim, onde eram publicadas as decisões do imperador, para que todo o império fosse informado. Chamavam-se acta diurna, e chegavam aos governantes de todos os pontos do mundo então conhecido.

Também na política dentro de Roma, a importância dos grandes oradores era muito grande. Anteriormente, ainda no período republicano, foi um grande discurso que mudou os rumos da história:

Brutus matou Júlio César, seu protetor, para salvar a República; tentava evitar a ascensão de um ditador, mesmo que este ditador fosse seu amigo. Um único discurso - o esplêndido discurso de Marco Antônio à beira do túmulo de César mudou a imagem que seria transmitida pela História: transformou o aspirante de ditador em herói e o salvador da República em traidor (BRICKMAN, 1998, p.161).

Embora essa comunicação do poder na Antigüidade não tivesse ainda os instrumentais de planejamento e pesquisa presentes nas grandes campanhas do século XX, Domenach (1963, p.8) diz que "desde que existem competições políticas, isto é, desde o início do mundo, a propaganda existe e desempenha seu papel. Foram, por certo, uma espécie de campanha de propaganda, aquelas movidas por Demóstenes contra Filipe ou por Cícero contra Catilina”.

Ao mesmo tempo, Domenach também demonstra que novamente a comunicação religiosa foi responsável pela utilização do termo que hoje usamos para os mais diversos tipos de comunicação persuasiva, seja ela a política, a de venda ou a religiosa: a propaganda.

A palavra que a designa é, ela também, contemporânea do fenômeno: propaganda é um dos termos que destacamos arbitrariamente das fórmulas do latim pontifical; empregada pela Igreja ao tempo da Contra-Reforma (De Propaganda Fide), é mais ou menos reservada ao vocabulário eclesiástico até irromper na língua comum, no curso do século XVIII (DOMENACH, 1963, p.10).

Nota-se aí novamente a estreita relação histórica entre política e religião no desenvolvimento da comunicação persuasiva.

1.1 A comunicação na concepção do Estado moderno

Comum. \& Inf., v. 15, n. 2, p. 97-115, jul./dez. 2012 
A partir do século XV, já no final da Idade Média, quando as primeiras concepções do Estado moderno razoavelmente separadas da dominação da Igreja apareciam, a preocupação com a comunicação e com o desenvolvimento da imagem pública dos governantes também era de extrema importância.

Num dos principais clássicos da Ciência Política, O Príncipe, desenvolvido no intuito de aconselhar um nobre italiano sobre a conquista e a manutenção do poder, Maquiavel (1995, p.107136) se preocupa com questões como o desenvolvimento pelo mandatário de uma imagem de cruel ou piedoso frente ao povo, de como ele deveria prometer benefícios e manter a palavra dada, além de dizer como ele deveria evitar ser desprezado ou odiado e também como saber se comportar para ser considerado pela nobreza e pelo povo. Um desses conselhos diz:

Deve um príncipe, contudo, ter grande cuidado para que jamais the saia da boca algo que não esteja prenhe daquelas cinco qualidades, parecendo, assim, aos que vêem e ouvem, todo piedade, todo lealdade, todo integridade, todo humanidade, todo religião. E nada mais é necessário aparentar possuir do que esta última qualidade. Os homens, em geral, julgam mais com a vista do que com o tato, eis que ver é dado a todos, sentir, a poucos. Todos vêem o que pareces ser, poucos sentes o que és; e estes poucos não ousam opor-se à opinião de muitos que contam com a majestade do Estado para a sua defesa (MAQUIAVEL, 1995, p. 113).

Essa preocupação com a opinião pública e com a importância de conseguir o apoio popular através de uma comunicação bem desenvolvida foi também de enorme importância na França, já entre os séculos XVII e XVIII, quando o "Rei Sol” Luís XIV, em seu grande período no trono, desenvolveu táticas bastante arrojadas. Burke (1992) diz que ele foi o precursor do marketing político moderno.

Queiroz (1999, p.70) ressalta que Luís XIV, para isso, foi o

indutor da criação de pinturas, tapeçarias, medalhas comemorativas, moedas, livros, construção de palácios, como o de Versailles, ou monumentos, como o Arco do Triunfo, além de ter sido ator teatral, entre outras ações desenvolvidas como o objetivo de torná-lo popular perante a sociedade francesa da época. (QUEIROZ, 1999, p. 70).

Já no final do século XVIII, durante o movimento de independência e de formação dos Estados Unidos da América, a utilização da comunicação persuasiva, principalmente através da imprensa, foi muito grande, com o intuito desenvolver uma formação política ao povo norteamericano. 
Vários artigos foram escritos, principalmente por Alexander Hamilton, James Madison e John Jay, e publicados em jornais de Nova York. Suas defesas da forma federalista, contrário à Confederação, contribuíram para a formação da Constituição dos Estados Unidos, e conquistaram a população para essa causa.

Segundo Limongi (apud WEFFORT, 1999, p. 249), tais artigos tinham como intenção demonstrar ao povo americano que o controle dos governos deveriam estar o mais próximo possível, de preferência nos Estados. Essa foi uma das primeiras e mais importantes utilizações de veículos de comunicação de massa para a conquista de reformas políticas com o apoio popular.

Pode-se ainda verificar a utilização de aparatos de comunicação de massa para a conquista da população também durante a Revolução Francesa, pelos mais diversos grupos que a desenvolveram. De acordo com Domenach,

os primeiros discursos de propaganda, os primeiros encarregados de propaganda (entre outros, os comissários junto aos exércitos) partiram dos clubes, das assembléias, das comissões revolucionárias; foram eles que empreenderam a primeira guerra de propaganda e a primeira propaganda de guerra. Uma nação, pela primeira vez, libertava-se e organizava-se em nome de uma doutrina subitamente considerada universal. Uma política interior e exterior, pela primeira vez, fazia-se acompanhar pela expansão de uma ideologia e, por isso mesmo, segregava a propaganda. Surgiram, então, todos os recursos da propaganda moderna: a Marselhesa, o barrete frígio, a festa da Federação, a do Ser Supremo, a rede dos clubes jacobinos, a marcha sobre Versalhes, as manifestações de massa contra as Assembléias, o cadafalso nas praças públicas, as críticas violentas de L’Ami du Peuple, as injúrias de Père Duchêne. (DOMENACH, 1963, p. 20-21).

Mais tarde, durante o século XIX, os diversos movimentos de caráter socialista usaram muito os veículos de comunicação de massa para conquistar trabalhadores de toda a Europa, o que resultaria num desenvolvimento ainda maior da propaganda no mais importante regime comunista resultante desse período, como se verá adiante. De acordo com Marx, era “preciso tornar a opressão real ainda mais dura, ajuntando-lhe a consciência da opressão, e tornar a vergonha ainda mais humilhante, dando-a publicidade" (apud DOMENACH, 1963, p. 26).

\subsection{O papel da comunicação nos três tipos de dominação legítima}

Como já foi visto, a principal função da comunicação política, desde seus primórdios, é a legitimação do poder. Governantes sempre necessitam, de alguma maneira, demonstrar à população os motivos pelos quais ele tem o direito de mandar, coordenar e decidir os rumos de todo o grupo. 
No entanto, embora sempre a comunicação tenha o papel de demonstrar a legitimidade, a dominação pode se dar de maneiras distintas.

No início do século XX, Max Weber (1970, p. 57) desenvolveu uma tipificação da dominação política. De acordo com ele, existem três razões internas que justificam a dominação, e, por conseguinte, existem três fundamentos da legitimidade. Num momento anterior, a autoridade do "passado eterno", que é a "dos costumes santificados pela validez imemorial e pelo hábito, enraizado nos homens, de respeitá-los". Este é chamado de "poder tradicional", que o patriarca ou o senhor das terras exercia. Neste tipo de dominação estão as teocracias, nas quais em geral há uma relação entre o governante e alguma divindade ou uma outra tradição histórica, fazendo-o ser seu representante ou seu descendente direto. Para a manutenção do poder tradicional, há a necessidade da construção de relatos e histórias que legitimem essa relação, de forma que os governados acreditem e aceitem a dominação.

Em segundo lugar, Weber expõe a

autoridade que se funda em dons pessoais e extraordinários do indivíduo (carisma) - devoção e confiança estritamente pessoais depositadas em alguém que se singulariza por qualidades prodigiosas, por heroísmo ou por outras qualidades exemplares que dele fazem o chefe. Tal é o poder "carismático". (WEBER, 1970, p. 57).

Este tipo de dominação era exercido na Antigüidade pelo profeta ou pelo chefe guerreiro. Além disso, grandes generais, demagogos e dirigentes de partidos políticos podem ser incluídos. A comunicação neste caso é extremamente importante para apresentar e desenvolver a imagem pública do líder carismático, fazê-lo se manter como tal, sem que o povo se decepcione ou deixe de acreditar nos seus "poderes extraordinários".

Ainda existe o terceiro tipo de dominação legítima, que é o baseado na “'legalidade’, em razão da crença na validez de um estatuto legal e de uma 'competência' positiva, fundada nas regras racionalmente estabelecidas ou, em outros termos, a autoridade fundada na obediência, que reconhece obrigações conformes ao estatuto estabelecido" (WEBER, M., 1970, p. 57-58).

Essa é a tipo "racional-legal" de dominação, em que é importante o respeito às leis, às normas e às regras propostas e aprovadas anteriormente. É o tipo de dominação que hoje se encontra na maioria dos países ocidentais, onde o respeito a uma Constituição é a principal razão da manutenção do governo. Neste caso, a comunicação é importante para mostrar aos governados as ações dos governantes, destacando a legalidade dos seus atos. 
Sobre a obediência, Weber diz:

É indispensável dizer que, na realidade concreta, a obediência dos súditos é condicionada por motivos extremamente poderosos, ditados pelo medo ou pela esperança - seja pelo medo de uma vingança das potências mágicas ou dos detentores do poder, seja a esperança de uma recompensa nesta terra ou em outro mundo. A obediência pode, igualmente, ser condicionada por outros interesses e muitos variados. (...) Seja como for, cada vez que se propõe interrogação acerca dos fundamentos que "legitimam" a obediência, encontram-se, sempre e sem qualquer contestação, essas três formas "puras", que acabamos de indicar. (WEBER, 1970, p. 58).

No entanto, embora esses três tipos sejam importantes para a compreensão da dominação política, ainda segundo Weber (1970, p. 58) "na realidade, só muito raramente se encontram esses tipos puros". Na verdade, as estruturas de poder e os governantes se mantêm, em geral, graças à junção de dois ou mesmos dos três tipos de dominação, para que todo o povo os aceite.

É importante notar então que determinadas ações de comunicação política têm funções específicas de apresentar à população algumas dessas características do governante, podendo ser um resgate de tradições históricas anteriores, uma demonstração de suas qualidades "superiores" ou “extraordinárias", revelando-o um homem ideal para o poder, ou ainda levando a crer que os aspectos racionais e legais estão sendo respeitados, constituindo um ambiente de normalidade e respeito às normas.

\subsection{Propaganda política nos regimes totalitários}

De acordo com Antonio Gramsci, citado por Maria Helena Weber (2000, p.151), dois tipos de controle político são usados para que seja garantido o funcionamento de um regime:

a dominação direta do conjunto da sociedade, através da força e da coerção física, e a direção exercida através do controle e dominação ideológicos. Nenhum Estado, no entanto, funciona desenvolvendo apenas ações repressivas; em algum momento, ele tem de conquistar a legitimidade e obter o consenso do conjunto da sociedade, em particular das classes subalternas. No século XX, os governos têm realizado grandes investimentos - políticos e financeiros - para criar complexas estruturas de comunicação. Essa estratégia transformou o exercício do poder ditatorial e demonstrou quão eficaz pode ser a comunicação para a política. (GRAMSCI apud WEBER, M. H., 2000, p. 151). 
Por isso, no estudo da propaganda política, é preciso recorrer a alguns momentos históricos fundamentais do século XX. Foi durante todo este século que se viu com ênfase a propaganda como uma das grandes armas para a manutenção dos poderes nos regimes totalitários.

Historicamente, os regimes totalitários sempre têm a presença de grandes aparatos de comunicação e propaganda. Seja nos regimes de Lênin, Hitler, Stálin ou Mao Tsé-Tung, mesmo quando fundados por uma grande repressão e coerção, o papel da propaganda é fundamental para a manutenção do poder.

Em uma discussão sobre totalitarismo, Heller diz:

Não existe apenas um tipo de totalitarismo, e sim várias espécies de sociedades totalitárias. O sistema nazista foi apenas um dos sistemas totalitários. (...) Para mim, regime totalitário é todo aquele em que o pluralismo é privado de legalidade. É evidente que não há sociedade moderna na qual não exista pluralismo. Mas no sistema totalitário os partidos e seus líderes decidem o que deverá ou não ser ilegal. E o que excluem do domínio da legalidade é, por definição, pluralismo. Podem ser excluídas a pintura, as poesias de amor, entre outros. (HELLER, 2002, p. 40-41).

E, nesses regimes, a propaganda sempre foi de extrema importância, com a intenção de legitimar o poder, visando ainda à propagação de idéias do grupo que governava, a fim de que toda a população as aceitasse.

A propaganda como "uma empresa organizada para influenciar a opinião pública e dirigi-la" (DOMENACH, 1963, p. 13) surgiu no século XX, com o intuito de amparar esses regimes. Para isso, utilizou-se de uma evolução que trouxe seu campo de ação, a massa, e os meios de ação, representada pelas técnicas recém-inventadas de informação e comunicação.

Domenach (1963, p. 13-17) traz ainda alguns fatos fundamentais para que isso fosse possível: a formação de noções de estrutura e espírito cada vez mais unificados e ainda uma revolução na demografia e no hábitat. Com isso, e mais ainda com o progresso dos meios de comunicação, a formação de grandes conglomerados urbanos, a insegurança da condição industrial, as ameaças de crise e de guerra, a que se juntavam vários fatores de unificação, como a língua e os costumes, houve uma criação de massas famintas por informação. Essas massas recém-formadas eram facilmente influenciáveis, suscetíveis a reações coletivas das mais diversas.

As inovações tecnológicas vinham dar uma dimensão aos três sustentáculos da propaganda: a escrita, a palavra e a imagem. O emprego deles, anteriormente limitados, pois a palavra não passava do alcance da voz humana ou de processos de impressão caros, assim como a reprodução de imagens, deu novas possibilidades à conquista das opiniões das massas. 
Para Domenach (1963, p. 15), a difusão da escrita impressa no século XVIII possibilitou o emprego de panfletos, jornais, livros e até mesmo de uma enciclopédia como forma de propaganda revolucionária. Com a invenção da rotativa, os valores de impressão ficaram muito menores, com uma capacidade de tiragem muito superior a preços menores.

Além disso, a utilização da publicidade comercial nos jornais fez com que houvesse maiores recursos para sua confecção, sem a necessidade de contar com ajuda governamental para realizálos. Quanto à distribuição, as estradas de ferro, os automóveis, e logo depois os aviões, possibilitaram a chegada de exemplares nos mais diversos cantos dos países e até mesmo do mundo, levando mensagens que anteriormente eram impossíveis de chegar.

Também como inovação tecnológica, houve uma grande aceleração do tráfego de informações, com o telégrafo e o telefone, que substituíram os processos antigos dos correios e dos pombos-correios. Com isso, era criado o jornal moderno, “cujo baixo preço e cuja apresentação o transformam em um instrumento popular e uma formidável potência de opinião". Então, ao mesmo tempo em que se popularizam, os jornais (juntamente com as agências de notícias) se tornam grandes negócios, a serviço também de seus anunciantes e dos detentores do poder (DOMENACH, 1963, p. 16).

Também com as inovações tecnológicas, não só a escrita chegou a todos os cantos. A palavra falada, que também era limitada, libertou-se. Segundo Domenach (1963, p. 17), enquanto oradores antigos, como Demóstenes, tinham que competir nas suas falas com o barulho do mar, a invenção do microfone pôde ampliar a voz para grandes salas e estádios.

Outra invenção fez com que as vozes do poder pudessem ser ouvidas em todos os cantos do mundo: o rádio. No início do século $\mathrm{XX}$, um grande número de estações de rádio se formou, e principalmente na formação do nazi-fascismo e durante a Segunda Guerra Mundial, sua utilização foi de extrema importância.

Quanto à imagem, também as inovações tecnológicas fizeram com que ela fosse muito utilizada como peça de propaganda para as massas. Primeiramente, com novos processos de reprodução de gravuras, juntamente com a imprensa. Depois, com a invenção da fotografia e sua possibilidade de tiragens ilimitadas, o público passou a ter a sensação de presenciar a verdade, como se estivesse presente no momento dos acontecimentos.

Ainda de acordo com Domenach (1963, p. 18), "o cinema oferece uma imagem mais verídica e surpreendente, que se afasta da realidade apenas pela ausência do relevo". Porém, a 
televisão ainda viria para realizar com a imagem a mesma mágica que o rádio realizou com o som: transmiti-la de forma instantânea à casa das pessoas.

\subsubsection{Tipos de propaganda política}

A partir do novo momento e das possibilidades para desenvolver a propaganda política, Tchakhotine (1967) demonstra dois tipos de propaganda política: a propaganda por persuasão (racio-propaganda) e a propaganda por sugestão (senso-propaganda) (apud PICOLIN, 2001, p.2021).

Sobre a propaganda por persuasão, Tchakhotine diz que

suas modalidades são conhecidas: jornais, discursos pelo rádio, reuniões com debates, brochuras e boletins, enfim, a propaganda pessoal ou de porta em porta, quando os propagandistas vão às portas das pessoas que lhes interessam para tentar demonstrar-lhes os fundamentos de seus programas e persuadi-las a se inscrever no partido que representam ou a votar nele. (TCHAKHOTINE, 1967, P. 353).

Para isso, é necessário que haja um planejamento de acordo com os grupos que se quer influenciar, além de se estabelecer objetivos a serem atingidos, formar órgãos para realizar as ações coordenadamente e controlar os resultados, verificando seus efeitos no público escolhido.

Já a propaganda por sugestão é aquela utilizada de maneira mais direta em momentos de grande importância:

Por meio de símbolos e ações que atuam sobre os sentidos, que causam emoções, procura-se impressionar as massas, aterrorizar os inimigos, despertar agressividade de seus próprios partidários. Além dos símbolos gráficos, plásticos e sonoros (...) são especificamente o emprego de bandeiras, uniformes, grandes manifestações, desfiles estrepitosos que caracterizam a propaganda deste tipo, empregada pelos ditadores (TCHAKOTINE, 1967, p.354).

Ainda nas definições de tipos de propaganda política, pode-se encontrar a tipificação definida por Muchiaelli (1978), como citada também por Picolin:

- Propaganda de doutrinação, de expansão e de recrutamento - é a que visa conquistar a opinião pública e ampliar o espaço da doutrina política no momento em que conquistar o poder.

- Propaganda de agitação - tem a intenção de explorar as reivindicações e as aspirações frustradas dos grupos sociais, conhecendo bem suas necessidades.

- Propaganda de integração - tem como função criar uma unidade ideológica a fim de propiciar, ao grupo ou indivíduo que está no poder, legitimidade e autoridade, integrando o cidadão ao poder, fazendo-o sentir como mais um decisor. 
- Propaganda de subversão - é a que visa realizar uma revolução tomando por base as condições psicológicas dos elementos do corpo social. (PICOLIN, 2001, p. 22).

Domenach (1963) também desenvolve uma divisão da propaganda política em dois tipos, a partir de dois grandes momentos da história do século XX: a Revolução Russa de 1917 e a ascensão do nazismo na década de 1930. São a propaganda de tipo leninista e a propaganda de tipo hitlerista.

\subsubsection{Propaganda leninista}

Para explicar a propaganda de tipo leninista, Domenach $(1963$, p.21) faz uma discussão sobre o marxismo, dizendo que ele pode ser caracterizado pelo seu poder de difusão: "trata-se de uma filosofia capaz de propagar-se entre as massas, de início porque corresponde a certo estágio da civilização industrial, depois porque repousa em uma dialética que pode ser reduzida à sua extrema simplicidade, sem deformar-se substancialmente". No entanto, é importante lembrar que Lênin foi quem colocou em prática grande parte desta capacidade de expansão.

Para Lênin, então, deveria ser importante para o sucesso da revolução a presença de agitadores no partido, com a função de sensibilizar e arrastar as massas. Passava-se depois da agitação para a educação política.

Domenach (1963, p.22) diz ainda que "a propaganda bolchevique (ou leninista) pode ligarse a duas expressões essenciais: a revelação política (ou denúncia) e a palavra de ordem”.

É aí que, de acordo com Quintero,

Domenach assinala a radical diferença entre a propaganda leninista e a propaganda hitlerista. Segundo ele, a concepção leninista da propaganda é "a tradução da tática", mas seus slogans correspondem sempre a uma realidade. Quando Lênin diz "terra e paz", realmente se propõe expropriar as terras dos latifundiários e assinar a paz com os alemães. Quando Goebbels afirma que a Alemanha vai ganhar a guerra em "defesa da civilização cristã", isso não é mais do que uma fórmula destinada a mobilizar as massas que não corresponde a uma realidade (tradução minha). (QUINTERO, 1990, p. 331).

Vale lembrar também que, na concepção da propaganda hitlerista, não existe a presença do conteúdo de formação doutrinário e intelectual presente na propaganda leninista.

Sobre a palavra de ordem neste tipo de propaganda, ela tem uma função específica, como um conceito criativo ou um slogan, em que se traduz verbalmente uma tática revolucionária. "Conceito motriz, expressa o objetivo mais importante do momento", o mais claramente possível (DOMENACH, 1963, p.22).

Como exemplo, foram criados: "Todo poder aos sovietes", "Pão, paz e liberdade", "Por um governo de ampla união democrática”, entre outras. Essas palavras de ordem, também, além dessas 
características, deveriam corresponder não só à situação política, mas também ao nível de consciência das massas, isto é, uma adaptação da mensagem às condições de percepção e compreensão do público-alvo.

Este tipo de propaganda foi desenvolvido também em outras revoluções marxistas, no Europa do Leste depois da Segunda Guerra Mundial, na China de Mao Tsé-Tung, além do Vietnã e da Coréia do Norte, sempre com a preocupação de formar um "novo homem", e não de apenas conquistá-lo para uma única ação.

A escola torna-se um dos pilares dessa propaganda total. Em seguida, dos "seminários políticos", das "escolas de aperfeiçoamento" e dos "círculos de estudos" saem, formados, centenas de milhares de "propagandistas" ou agitadores que dão cursos políticos, realizam palestras nas fábricas, nos kolkozes, nos estabelecimentos comerciais e em instituições de toda espécie. As obras de Marx, de Engels, de Lênin, de Stálin e de Mao Tse-Tung formam a base desse ensino. Tão gigantesco trabalho é escorado em inúmeras associações culturais, que enxameiam nos "recantos vermelhos" das fábricas, nas "isbás de leitura" nos campos, nas sociedades beneficentes do Exército, nos clubes esportivos e em outras agremiações (DOMENACH, 1963, p. 26).

\subsubsection{Propaganda hitlerista}

Sobre a propaganda do nazismo, chamada de hitlerista, é importante compreender a sua importância para o desenvolvimento da propaganda moderna. Joseph Goebbels, o responsável pela comunicação do Terceiro Reich, transformou o que era até então entendido como propaganda. De acordo ainda com Domenach,

a propaganda hitlerista mergulha suas raízes nas mais obscuras zonas do inconsciente coletivo, ao gabar a pureza do sangue, ao glorificar os instintos elementares de violência e destruição, ao renovar por meio da cruz gamada a remotíssima mitologia solar. Ademais, emprega sucessivamente termos diversos e até contraditórios com a única preocupação de orientar multidões ante as perspectivas do momento. (DOMENACH, 1963, p. 28).

Vale destacar que o regime nazista foi convenceu uma grande parte da população alemã, formada por muitas pessoas cultas, de que eles eram o centro de uma raça superior, sob a liderança de Adolf Hitler. Loiros do norte, morenos do sul, eslavos do leste, descendentes de godos, hunos, alamanos teutões, celtas, todos eles pertenciam a uma mesma raça, única e superior. De acordo com Brickmann (1998, p.158-159), Goebbels conseguia tudo isso praticando as idéia de que "uma 
mentira se torna verdade se repetida mil vezes" e "é mais fácil acreditar numa grande mentira do que numa pequena".

Quintero destaca que já em Mein Kampf (Minha luta), o livro de Hitler em que ele desenvolvia a idéia inicial do nazismo, havia a preocupação com o papel da propaganda:

O papel que a propaganda deve realizar é o de continuar conquistando partidários para a idéia, ao passo que o objeto da organização é o de converter os melhores simpatizantes em membros ativos do Partido (...). O primeiro dever da propaganda está em conquistar homens para a organização; e o da organização, em conquistar homens para continuar a propaganda. O segundo dever da propaganda é o de acabar com a situação existente, através de uma nova doutrina; e o da organização, lutar pela conquista do poder, a fim de assegurar a partir daí o êxito final da doutrina. (QUINTERO, 1990, p. 333).

Para o bom funcionamento dos instrumentos de comunicação e propaganda, Hitler, já no poder, instituiu um ministério próprio para esse fim, chamado de Ministério de Cultura Popular e Propaganda. De acordo com Quintero (1990, p.337), a função de Goebbels, o titular da pasta, era ser o "encarregado de tudo aquilo que se referia a 'direção espiritual da nação"”. Embora parecendo um termo vago e muito geral, isso indicava o que a propaganda representava para os nazistas: ela era muito mais do que um instrumento; era na realidade toda a sua política.

Com isso, todas as formas de comunicação passaram a ser controladas e desenvolvidas especificamente para as finalidades já previstas pela equipe do ministério. Havia seções que cuidavam da propaganda ativa, do rádio, do cinema, da imprensa e uma que cuidava da cultura do partido, com repartições de artes criativas, música e literatura. Segundo Quintero (1990, p.337), foram criadas novas seções dedicadas à propaganda externa e à imprensa estrangeira, além de uma área dedicada exclusivamente ao turismo, visto também como uma grande ferramenta de comunicação persuasiva.

Embora tivessem todos os meios de comunicação em suas mãos, os nazistas se destacaram na utilização da palavra falada muito mais do que da palavra escrita. O rádio foi, sem dúvida, o principal desses meios, através de transmissões da palavra do Führer para toda a Alemanha. O cinema, os cartazes, a pintura, a escultura, a arquitetura, a literatura e a música também foram fundamentais para o sucesso da propaganda hitlerista, tanto internamente quanto nos outros países, preparando um possível momento de expansão do regime.

De acordo com Domenach (1963, p.29), a propaganda nazista utilizava, para atingir seus objetivos, um condicionamento realizado em larga escala, utilizando o instinto de poder, "de início, 
formando os reflexos e pondo-os em funcionamento; em seguida, utilizando-os no ritmo necessário para criar o estado de inibição". Com isso, o resultado era que

entre os homens que seguiam Hitler até o fim e por ele morriam, muitos, por certo, o tinham odiado; os processos e o ritmo da propaganda, contudo, os tinham hipnotizado e arrancado de si mesmos. Condicionados até a medula, haviam perdido a possibilidade de compreender, de odiar. Não amavam nem detestavam Hitler: na verdade, fascinados por ele, tinham-se tornado autômatos em suas mãos (DOMENACH, 1963, p.32).

\subsubsection{Meios, leis e técnicas da propaganda política}

A partir do estudo dos dois principais tipos de propaganda política desenvolvidos durante o século XX, Domenach demonstra seus “poderosos e inúmeros” suportes técnicos:

- $\quad$ O impresso - representado pelo livro que, embora caro, é importante como instrumento de base, além do panfleto, do folheto, do volante e do cartaz. Como destaque, o jornal é apontado como o principal instrumento da propaganda impressa, tanto os grandes matutinos e vespertinos como os jornais de bairro e de fábrica, distribuídos e afixados (os jornais murais).

- A palavra - através do rádio, como maior e mais importante veículo, pela sua alta penetração na população. Também é destacado o alto-falante, para grandes discursos e para chamar a atenção em comícios, e o canto, para traduzir palavras de ordem em melodia, como se pode ver na Marselhesa e na Internacional.

- A imagem - com a fotografia, a caricatura, os desenhos satíricos, os símbolos, os emblemas, é possível conquistar o receptor sem grandes esforços, com uma possibilidade de compreensão na maioria das vezes maior do que com a palavra escrita.

- O espetáculo - é destacado como um elemento essencial da propaganda, com encenações, manifestações de massa gigantescas, como o Congresso de Nuremberg, paradas noturnas com tochas, tocando profundamente a mitologia. Também como exemplos de espetáculos estão o teatro, o cinema e, mais recentemente, a televisão, que também possui o principal benefício do rádio, que é chegar às casas das pessoas comuns. (DOMENACH, 1963, p. 33-37).

Depois de relatar os diversos suportes para a propaganda política, Domenach desenvolve as principais leis de seu funcionamento, suas "regras de uso":

- $\quad$ Lei de simplificação e do inimigo único - a propaganda deve sempre se empenhar na busca da simplificação, dividindo a doutrina e a argumentação em alguns pontos, definidos o mais claramente possível, traduzindo-os em slogans ou símbolos, para que sejam utilizados um de cada vez, atacando a cada fase um só objetivo e um só "inimigo".

- Lei de ampliação e desfiguração - a ampliação exagerada de notícias, que é um processo jornalístico empregado de forma corrente pela imprensa de todos os 
partidos, colocando em evidência todas as informações favoráveis aos seus objetivos. As promessas, nesse caso, não devem ser pormenorizadas, mas sim desenvolvidas de modo mais surpreendente.

- Lei de orquestração - a repetição incansável das idéias simplificadas, através de formas diversas e em todos os meios possíveis, para que o receptor se veja cercado por elas. Também devem ser desenvolvidas versões para que todos os tipos de público compreendam plenamente o que está sendo afirmado.

- Lei da transfusão - a exploração, nos temas apresentados, do gosto popular, de sua mitologia, de seu complexo de preconceitos, de seus ódios, de seus amores, para que as pessoas vejam nas mensagens referências ao que elas, consciente ou inconscientemente, desejam ou concordam.

- Lei da unanimidade e de contágio - como as pessoas tendem a ter comportamentos e opiniões diferenciadas quando agem como indivíduos ou como membros de um grupo, deve-se preocupar para que haja na propaganda a impressão ou a ilusão de unanimidade, fazendo com que as pessoas creiam que estão ao lado da maioria de seu grupo. Isso também funciona com contágio, através de grandes manifestações populares. (DOMENACH, 1963, p. 40-45).

\subsection{Propaganda ideológica}

A propaganda política, embora possa ter sua origem conhecida pelo público receptor, quando há uma assinatura do emissor da mensagem, um partido político ou um determinado homem público ou candidato, em grande parte das vezes age através da não-identificação. Neste ponto é que ideologias são transmitidas: é onde se encontra a propaganda ideológica.

De acordo com a filósofa Marilena Chauí,

ideologia é um conjunto lógico, sistemático e coerente de representações (idéias e valores) e de normas ou regras (de conduta) que indicam e prescrevem aos membros da sociedade o que devem pensar e como devem pensar, o que devem valorizar e como devem valorizar, o que devem sentir e como devem sentir, o que devem fazer e como devem fazer. (CHAUÍ, 1998, p. 113-115).

É importante notar que a propaganda ideológica funciona de maneira diversa da publicidade institucional, pois essas mensagens são veiculadas de maneira indireta, em veículos que tentam passar uma imagem neutra.

$\mathrm{Na}$ propaganda de regimes totalitários, existe um condicionamento ideológico, reforçado ainda mais pelo aparelho de coerção do Estado, que controla tanto a mídia quando as próprias relações da sociedade. Segundo Weber, M. H.,

a técnica principal da propaganda política autoritária visa apresentar o governo como intérprete das idéias, dos interesses, dos valores populares, exaltando seus esforços para responder às aspirações do povo, que só ele pode entender e interpretar, e viabilizar seu futuro. As contradições entre Estado e sociedade são 
ocultadas e os interesses particulares das classes dominantes são ideologicamente transformados em interesses de toda a sociedade. (WEBER, M. H. 2000, p. 145).

E isso ocorre nos veículos de comunicação. Jornais e revistas têm na população em geral uma imagem de detentores e reprodutores da verdade dos fatos. Por isso, qualquer mensagem com intenções de convencimento e que tenha origem em algum grupo de poder pode ser caracterizada como propaganda ideológica, com a função de formar a maior parte das idéias e convicções dos indivíduos, e, com isso, orientar todo o seu comportamento social.

Segundo Weber, M. H.,

quando dirigida pela democracia, a comunicação expõe o governo e estabelece entendimentos com a sociedade, sendo submetida ao controle desta, das mídias e de instituições diversas. As organizações midiáticas, por sua vez, optam pelo tipo de vínculo a ser estabelecido com o governo instituído. Quando recurso do totalitarismo, a comunicação mascara, amplia, reduz e omite informações, verdades e realidades, e controla os meios de comunicação, produzindo informações e propaganda. (WEBER, M. H. 2000, p. 140).

É importante notar ainda que há uma grande profusão de termos utilizados nos estudos de comunicação política. Ainda de acordo com Weber, M. H.,

diferentes formas de exercício retórico da política são registradas na história, como: a) propaganda político-ideológica - a serviço de ideologias, como comunismo, nazismo; b) o marketing - a serviço de partidos políticos e eleições, como a propaganda eleitoral; c) a propaganda institucional, quando vinculada à publicidade de órgãos e dirigentes governamentais. (WEBER, M. H. 2000, p. 140141).

No caso do regime militar no Brasil, por exemplo, é importante notar que havia a utilização da propaganda institucional, em determinadas ações em que aparecia a assinatura e a identificação precisa do emissor da mensagem. Além disso, havia a propaganda ideológica, que, de acordo com Garcia (1982b), não mostra o verdadeiro emissor da mensagem, e pretende convencer o receptor travestida como verdade.

De acordo com Garcia (1982b), citado também por Queiroz (2001, p.67-71), alguns temas são importantes para a discussão: o controle ideológico, a contrapropaganda, a difusão e os efeitos da propaganda ideológica.

- Controle ideológico - faz com que as pessoas não consigam perceber a própria realidade e não possam reconhecer a própria opinião. Como os indivíduos só 
podem adquirir consciência de suas reais condições de vida através da observação direta ou através de informações recebidas (através dos meios de comunicação ou do contato com outras pessoas), o controle ideológico faz com que eles só consigam compreender a complexidade de seu contexto com o filtro de meios de comunicação com fins específicos de fazê-los crer numa ideologia qualquer.

- Contrapropaganda - trabalha empregando técnicas para amenizar impactos de possíveis mensagens opostas, anulando seu efeito persuasivo. Coloca-se sempre as idéias contrárias em contradição com a realidade, ou parte dela, para que os indivíduos não reconheçam nelas nenhuma verdade, mostrando-as também contrárias a valores dos indivíduos ou dos grupos sociais.

- Difusão - é a transmissão das idéias para os receptores pelos mais diversos meios, depois de sua codificação. Segundo QUEIROZ (2001, p.70), "é a partir da difusão que surge a possibilidade de produzir uma impressão de unanimidade tão persuasiva quanto os próprios argumentos do orador".

- Efeitos da propaganda ideológica - as idéias de um determinado grupo passam a ser disseminadas para o restante da sociedade de forma persuasiva. "Depois de emitidas através dos diversos meios de comunicação, elas passam a ser retransmitidas, direta ou indiretamente, no seio das diversas instituições sociais". Assim, a ideologia impregna a todos. (GARCIA, 1982b, p.78).

Com a intenção de demonstrar à sociedade uma determinada verdade, a utilização de veículos considerados "neutros" é fundamental para o sucesso da propaganda ideológica. Por isso, a imprensa sempre foi um dos principais meios de disseminação da ideologia dos grupos no poder. Através da cooptação de jornalistas e empresários de comunicação, seja pelo oferecimento de benefícios seja pela censura, tanto os Estados totalitários quanto os aparentemente democráticos, utilizam as páginas de jornais e revista e os programas jornalísticos do rádio e da televisão com o intuito de falar ao povo por via indireta.

Referências

Artigo submetido em 10/11/2012 e aceito em 17/02/2013.

BRICKIVIAININ, CarIos. A vida e um paranque: os segredos da comunicação política. São Paulo: Globo, 1998.

BURKE, Peter. A fabricação do rei: a construção da imagem pública de Luís XIV. Rio de Janeiro: Zahar, 1994.

CHAUÍ, Marilena. O que é ideologia. São Paulo: Brasiliense, 1998.

CITELLI, Adilson. Linguagem e persuasão. São Paulo: Ática, 2004.

DOMENACH, Jean-Marie. A propaganda política. São Paulo: Difusão Européia do Livro, 1963.

GARCIA, Nelson Jahr. O que é propaganda ideológica. [S. 1.]: Nobel, 1982. (Coleção primeiros passos). 
HELLER, Agnes. Agnes Heller entrevistada por Francisco Ortega. Rio de Janeiro: UERJ, 2002.

MAQUIAVEL, Nicolau. O Príncipe. São Paulo: Cultrix, 1995.

QUEIROZ, Adolpho. De Debret a Nizan: a construção da imagem pública dos governantes. Revista Brasileira de Ciências da Comunicação. São Paulo: Intercom, vol. XXII, n. 1, p. 69-77, 1999.

QUINTERO, Alejandro Pizzaroso. Historia de la propaganda. Madrid: Eudema, 1990.

TCHAKHOTINE, Serge. A mistificação das massas pela propaganda política. Rio de Janeiro: Civilização Brasileira, 1967.

WEBER, Maria Helena. Comunicação e espetáculos da política. Porto Alegre: Ed.

Universidade/UFRGS, 2000.

WEFFORT, Francisco. Os clássicos da política: v. 1. São Paulo: Ática, 1998.

WEFFORT, Francisco. Os clássicos da política: v. 2. São Paulo: Ática, 1999. 